\title{
$\underline{\text { Supervision of career counseling interns }}$
}

By: Marie B. Sumerel and L. DiAnne Borders

Sumerel, M. B., \& Borders, L. D. (1995). Supervision of career counseling interns. The Clinical Supervisor, 13(1), 91-100. https://doi.org/10.1300/J001v13n01_07

This is an Accepted Manuscript of an article published by Taylor \& Francis in The Clinical Supervisor on 03 October 1995, available online:

http://www.tandfonline.com/10.1300/J001v13n01 07

***;(C) 1995 The Haworth Press, Inc. Reprinted with permission. No further reproduction is authorized without written permission from Taylor \& Francis. This version of the document is not the version of record. Figures and/or pictures may be missing from this format of the document. ***

\begin{abstract}
:
Supervisors of career counseling interns in three settings (college/university career planning centers, college/university counseling centers, community colleges) described their supervisory approach, format, and focus, and indicated which career counseling competencies they emphasized in this baseline study. Results indicated that supervision practices were similar in the three settings: supervision occurred weekly and was based on self-report given by the intern in individual sessions. Supervisors emphasized the career counseling competencies of counseling skills and career information most often and consultation least often. Recommendations for future research on supervision and career counseling competencies are identified.
\end{abstract}

Keywords: counseling | intern supervision | career counseling interns | competency development Article:

Career counseling, historically, has been a central area in counselor training and practice. The National Career Development Association (NCDA) was an organized, functioning organization prior to the formation of its new parent organization, the American Counseling Association, was formed (Smith, Engels, \& Bonk, 1985). Today, career counselors are found in a variety of work settings, including public schools, community colleges, college/university career planning and placement offices, and college/university counseling centers.

Given the historical importance of career development and counseling to the profession, it is surprising to discover a paucity of literature on the training and supervision of career counselors (cf. Dorn, 1986). Relatively few authors have presented ideas for teaching core career counseling courses (for examples see Bradley, 1983; Miller \& Soper, 1982; Roark, 1983), and little attention has been given to advanced coursework in this area (Niles \& Pate, 1989). With respect to supervision of practica and internships in career counseling, only one published study was located. Fink, Allen and Barak (1986) described their approach to supervising career assessment interns in their university counseling center. The authors described three phases of the interns' 
development and supervisors' tasks during each phase (e.g., illustrating the appropriate use of assessment, emphasizing the "big picture" of the client, and teaching the "art of meaningful test interpretations").

It seems evident that, despite the historical and central role of career counseling, little is known about how counselors develop competency in this counseling specialty. Even basic information regarding the existence of career counseling internships and supervision practices are lacking. This state of affairs presents a dilemma for researchers who must identify the location of career counseling interns and determine appropriate outcome measures. As a result, opportunities to develop an informative body of literature on the training and supervision of career counselors is limited.

In light of the above, the purpose of this study was to obtain baseline information regarding several career counseling internship sites, supervision practices in those sites, and topics for further investigation. A survey was designed to gather descriptive data concerning career counseling internships (e.g., location of these internships; number of interns supervised; supervision frequency, approach, format, and focus) and to compare supervision practices in the various internship sites. In addition, we investigated the relative emphases given to the NCDA (1988) career competencies.

\section{METHODOLOGY}

\section{Participants}

The population of interest was all individuals involved in supervising master's-level career counseling interns in three types of settings in the mid-Atlantic: college/university career planning centers, college/university counseling centers, and community colleges. Different procedures were used to identify possible participants. To gather the names for college/university personnel in the first two settings, the membership directory of the professional association was consulted. College/university career counselors were identified via personal telephone calls to all appropriate members of the association $(N=38)$, excluding those in specialty programs (e.g., forestry, MBA). These persons were asked several questions during the phone call: (1) where career counseling was conducted (i.e., career planning center and/or counseling center), (2) whether the member bad supervised master's-level interns who were doing career counseling, and, (3) if career counseling for the campus was conducted in the college/university counseling center, the name of the person in the counseling center who was most likely to supervise the career counseling interns. Through these phone calls, it was determined that six campuses had no career interns in either the career planning center or the counseling center. Of the 42 surveys mailed to the remaining settings, 30 surveys were returned ( $70 \%$ return rate) and 24 were usable. (Six respondents returned their surveys indicating they had not supervised interns.) Of the 24, 11 were counselors in a university counseling center and 13 were counselors in a university career planning center.

For the third setting, a career counselor from each community college was identified by job title from the Student Development Services Staff Roster for the state community college system; one person on each of the 58 state community college campuses was included in the sample. Of the 
30 surveys returned (52\% return rate), 11 individuals had supervised interns and 10 were usable surveys. The remaining 19 indicated that they had not supervised master's-level in terns.

In summary, the above procedures yielded a total of 34 useable surveys: 11 in college/university counseling centers, 13 in college/university career planning centers, and 10 in community colleges.

\section{Survey Instrument}

A three-part survey was developed after a thorough review of similar previous surveys (e.g., Borders \& Usher, 1992; Hart \& Falvey, 1987; Holloway, 1982; McKenzie, Atkinson, Quinn \& Heath, 1986). In the first section, respondents provided background information (i.e., age, gender, ethnic group, counseling degrees, counseling orientation, amount of paid counseling experience, years of career counseling experience, training in counseling supervision, type of institution and office, number of years in current position, and number of master's and doctorallevel interns supervised). They also indicated frequency of supervision provided (e.g., weekly, monthly, etc.), timing of supervision in relation to the counseling session (e.g., prior to, during, or immediately after session, or delayed), supervision approach (e.g., self-report, review of tapes, co-therapy, or live observation of supervision), supervision format (e.g., individual, group, or staff case conference), and supervision focus (e.g., personal growth and emotional support of intern, case conceptualization and review, intervention techniques and skill development, intern's knowledge of career resources, and intern's knowledge of office procedures and administrative functions).

In the second section, the 39 career counseling competencies identified by the National Career Development Association (1988) were listed in random order (i.e., without the six general headings of general counseling skills, career information, individual and group assessment, management and administration, implementation, and consultation). Using a five-point Likert scale $(1=$ least important, $5=$ most important), supervisors indicated the extent to which they emphasized each competency when supervising interns. In the third section, respondents answered open-ended questions about what they believed contributed to and distracted from their effectiveness as a supervisor.

The survey was field tested by three doctoral students who had experience in counseling supervision and were aware of the career counseling internship process. Minor editorial revisions were made based on their feedback.

\section{Procedure}

The survey, cover letter, and a stamped, self-addressed return envelope were sent to identified participants (see previous section) during the spring and summer of 1990. The cover letter stated the purpose and focus of the research, a definition of supervision for the purposes of this study, a description of the survey, and a request for participation. It was indicated that the results would be reported in group form only, and that the individual responses would remain confidential. Because of the extensive preliminary work in identifying the sample through phone calls, no follow-up was conducted. 


\section{RESULTS}

\section{Characteristics of Respondents}

Supervisors $(n=34)$ were primarily female $(n=25)$, white $(n=31)$, and within the 30-39 $(n=$ $16)$ or $40-49$ age range $(n=11)$. Twenty-three respondents held a master's degree in counseling. Of the 12 supervisors who had received or were working on their doctorates, four were in counseling and three were in counseling psychology; the remainder were from clinical psychology, or "other." The counseling orientation preferred by 15 of the supervisors was eclectic; 12 preferred client-centered. The supervisors had 2 to 23 years of experience in career counseling $(M=10.19, S D=5.86)$. All respondents had supervised fewer than 7 master's-level interns and fewer than 3 doctoral-level interns during the previous two years. Twenty-one of the supervisors reported they had received no training in supervision.

\section{Characteristics of Supervision}

Frequencies were calculated for the total sample and each of the three settings. For all except the frequency of supervision item, respondents could check more than one response. Thus, for these items, responses may total more than 34 (total number of participants). (Percentages are not reported due to the small sample size.)

As appropriate (i.e., sufficient number per cell), Chi-square tests were used to determine any significant relationship between setting and (a) supervision approaches, (b) supervision format, and (c) supervision focus. As appropriate, categories for each of these analyses were collapsed to provide a more accurate and meaningful reflection of the responses given (e.g., combinations of group and peer group supervision, review of audio and videotapes, case review and conceptualization). Because of the exploratory nature of the study, an experiment-wise alpha of .10 was used as the significance level. Results of the frequency tabulations and Chi-square tests are summarized in the following sections.

A majority of the respondents $(n=25)$ provided supervision once a week. The remainder indicated that supervision wa5 provided every couple of weeks or "as needed" by the career counseling intern. With regards to timing of sessions, similar numbers of respondents indicated that supervision occurred just prior to, immediately following, or on a delayed basis with respect to the counseling session; less than half of the respondents $(n=12)$ said supervision occurred during the counseling session.

All respondents indicated that they provided individual supervision for the career counseling interns. For almost half of the respondents $(n=16)$, individual sessions were the only format employed. A substantial number $(n=18)$ also used staff case conferences for supervision. Only 6 respondents said they employed group supervision (with a leader); none reported use of peer group supervision at their site.

With regards to supervision approach, almost all the respondents $(n=32)$ indicated that they used self-report; they typically used this approach more than $50 \%$ of the supervision time. Other 
approaches used by a majority of the respondents included co-therapy $(n=21)$, live observation with the supervisor present $(n=20)$, and review of audiotapes $(n=17)$. These approaches, however, were employed for $25 \%$ or less of the supervision time. Few respondents said they relied on review of videotapes $(n=3)$, live observation via a one-way mirror $(n=1)$, or Jive supervision $(n=1)$.

Most respondents indicated that they gave some emphasis to each of the eight possible foci for supervision: personal growth $(n=32)$, emotional support $(n=32)$, skill development $(n=32)$, knowledge of administrative procedures $(n=29)$, case review $(n=30)$, knowledge of career resources $(n=30)$, intervention techniques $(n=25)$, and case conceptualization $(n=20)$.

Chi-square analyses revealed only one significant relationship between setting and frequency of use of supervision approach, format, and focus. In the approach to supervision, college/university career planning center supervisors said they were more likely to use live observation than did college/university counseling center supervisors, $X^{2}(2, N=34)=8.56, p=.01$.

\section{Career Counseling Competencies}

The ordering of career counseling competencies from most emphasized to least emphasized was the same for supervisors in each setting. As can be seen in Table 1, all supervisors reported that they gave the greatest emphasis to counseling skills and career information, and that they gave the least emphasis to consultation. A $3 \times 6$ mixed, within-subjects analysis of variance was used to analyze differences in the six career counseling competencies (within factor) emphasized by supervisors in the three settings (between factor). There was a significant interaction between settings and career counseling competencies $[F(10,155)=1.96, p=.0409]$, and a significant main effect for career counseling competencies $[F(5,155)=41.19, p=.0001]$. Simple effects, followed by Tukey's Studentized Range test where appropriate, were used to examine the interaction effect. Results indicated that supervisors in each setting gave equal emphasis to each of the first five career counseling competencies, but differed in their emphasis on consultation. College/university career planning supervisors rated consultation significantly lower than did community college supervisors.

Table 1. Means and Standard Deviations for Ratings on Six Subscales of Career Counseling Competencies by Setting

\begin{tabular}{|c|c|c|c|c|c|c|c|c|}
\hline \multirow[b]{2}{*}{ Subscale } & \multicolumn{2}{|c|}{$\begin{array}{c}\text { University } \\
\text { Counseling Centers } \\
(N=11) \\
\end{array}$} & \multicolumn{2}{|c|}{$\begin{array}{c}\text { University Career } \\
\text { Planning Ctr. } \\
(N=13) \\
\end{array}$} & \multicolumn{2}{|c|}{$\begin{array}{c}\text { Community } \\
\text { College }(N=10)\end{array}$} & \multicolumn{2}{|c|}{ Total $(N=34)$} \\
\hline & $M$ & $S D$ & $M$ & $S D$ & $M$ & $S D$ & $M$ & $S D$ \\
\hline Counseling Skills & 4.60 & .43 & 4.25 & .55 & 4.39 & .47 & 4.40 & .50 \\
\hline Career Information & 3.97 & .71 & 4.00 & .39 & 4.25 & .52 & 4.06 & .54 \\
\hline Individual \& Group Assessment & 3.81 & .55 & 3.37 & .85 & 3.99 & .67 & 3.69 & .74 \\
\hline Management \& Administration & 3.17 & 1.10 & 2.87 & .79 & 3.47 & .75 & 3.14 & .90 \\
\hline Implementation & 3.58 & .92 & 3.31 & .75 & 3.48 & .70 & 3.45 & .78 \\
\hline Consultation & 2.98 & 1.26 & 2.26 & .75 & 3.42 & .94 & 2.84 & 1.08 \\
\hline
\end{tabular}

Note: Subscales were drawn from NCDA's Vocational/Career Counseling Competencies (1988).

\section{DISCUSSION}


This study was designed to gather descriptive baseline information concerning supervision of career counseling interns in three settings. Because a primary purpose was to provide some directions for future researchers, in this section we will briefly summarize our findings and then give attention to implications for future work in this area.

In general, results indicated that supervision practices across the three settings were quite similar. (Although two significant differences were found, these results have little practical significance, given the exploratory nature of the study and the limited sample.) Supervisors reported conducting weekly individual supervision sessions that were based on interns' self-reports of their work. Their primary goals for supervision included personal and professional development of interns, with particular emphasis given to general career counseling skills and techniques. With regards to the specific career counseling competencies (NCDA, 1988), supervisors in all three settings said that they gave the most emphasis to counseling skills and career information and gave the least emphasis to consultation.

Our findings regarding supervision practices are similar to those reported for other internship settings (e.g., Hart \& Falvey, 1987), and the career competency emphases seem developmentally appropriate for master's-level interns (Loganbill, Hardy, \& Delworth, 1982; Stoltenberg, 1981 ), who most likely are involved in their first actual counseling experience. In addition, it appears that many of the conclusions voiced by other supervision researchers also hold true for career counseling interns (e.g., concern about over-reliance on self-reports (Bernard \& Goodyear, 1992; Borders, 1989; Borders \& Leddick, 1987]; need for supervisor training opportunities for field supervisors [Borders \& Usher, 1992; Hart \& Falvey, 1987; Holloway, 1982]). In short, our findings seemed to parallel those reported in the larger body of supervision literature.

Although our results in general supported existing reports, several specific issues regarding further research in this area were identified. First, locating career counseling internship settings is not an easy task. We spent some time in preliminary work to identify sites and the appropriate person (supervisor) to receive the survey. Previous professional relationships with a number of these persons was a distinct advantage. Although we believe we achieved a representative and diverse sample of specialized career counseling sites in the state, we also are aware that students in other settings, particularly public schools, provide career counseling as part of their internships. Future researchers will need to carefully consider the various sources of career counseling interns (and the differences between them) in light of their particular research questions.

A second issue for future research on career counseling training and supervision concerns appropriate dependent measures. Our preliminary work suggests that the NCDA (1988) career counseling competencies are a relevant and promising avenue. Additional studies of a broader (i.e., national) population are needed to verify the relative emphases given to the competency categories across internship settings. The competency statements also could be the basis for outcome measures in investigations of the effectiveness of various training and internship experiences, desired sequences for teaching the six career competencies, and the appropriate "match" of training and supervision interventions with each competency area. 
Results of this exploratory study indicate that training and supervision of counselors within specialty fields such as career counseling deserve further investigation. Studies such as these suggested above might provide instructive results regarding the effectiveness of training and supervision practices, and could strengthen the long tradition of the career counseling field.

\section{REFERENCES}

Bernard. J. M., \& Goodyear, R. K. (1992). Fundamentals of clinical supervision. Needham Heights. MA: Allyn \& Bacon.

Borders. L. D. (1989). A pragmatic agenda for developmental supervision research. Counselor Education and Supervision, 29. 16-24.

Borders. L D., \& Leddick, G. R. (1987). A nationwide survey of supervision training. Counselor Education and Supervision, 27. 271-283.

Borders. L. D., \& Usher, C. H. ( 1992). Post-degree supervision: Existing and preferred practices. Journal of Counseling and Development, 70. 594-599.

Bradley, R. W. (1983). Teaching preservice career counseling classes. Vocational Guidance Quarterly, 32, 119-121.

Dorn, F. J. (1986). Needed: Competent. confident. and committed career counselors. Journal of Counseling and Development, 65, 216-217.

Fink, R., Allen, R., \& Barak, A. (1986). Teaching and supervising career assessment interns. Michigan Journal of Counseling and Development, 17(2). 27-30.

Hart, G. M., \& Falvey, E. (1987). Field supervision of counselors in training: A survey of the North Atlantic Region. Counselor Education and Supervision, 22, 204-212.

Holloway, E. L. (1982). Characteristics of the field practicum: A national survey. Counselor Education and Supervision, 22, 75-80.

Loganbill, C., Hardy, E., \& Delworth, U. (1982). Supervision: A conceptual model. The Counseling Psychologist, 10(1). 3-42.

McKenzie. P. N., Atkinson. B. J., Quinn, W. H., \& Heath, A. W. (1986). Training and supervision in marriage and family therapy: A national survey. American Journal of Family Therapy, 14, 293-303.

Miller, M. J., \& Soper, B. (1982). The art of creating enjoyable career counseling classes. Vocational Guidance Quarterly, 31. 144-148. 
National Career Development Association. (1988). The professional practice of career counseling and consultation: A resource document. Alexandria. VA: American Association for Counseling and Development.

Niles, S. G., \& Pate, Jr., R. H. (1989). Competency and training issues related to the integration of career counseling and mental health counseling. Journal of Career Development, 16(1). 6371.

Roark, M. L. (1983). More art in the career counseling classroom. Vocational Guidance Quarterly 32, 116-118.

Smith, R. L., Engels, D. W., \& Bonk, E. C. (1985). The past and future: The National Vocational Guidance Association. Journal of Counseling and Development, 63, 420-423.

Stoltenberg, C. (1981). Approaching supervision from a developmental perspective: The counselor complexity model. Journal of Counseling Psychology, 28. 59-65. 